\title{
Perception of Climate Change: Reasons, Consequences, and Willingness to Act. How Aware are They?
}

\author{
Burckin Dal ${ }^{1}$, Nilay Ozturk ${ }^{2}$, Umut Alper ${ }^{3}$ \\ Duygu Sonmez ${ }^{4}$, Muhammet Emin Misır ${ }^{5}$ Aytekin Cökelez ${ }^{6}$ \\ Istanbul Technical University ${ }^{1}$ (Turkey), Middle East Technical University ${ }^{2}$ (Turkey), Atılım \\ University $^{3}$ (Turkey),Hacettepe University (Turkey), Bosphorus University (Turkey), Ondokuz \\ Mayıs University (Turkey) ${ }^{6}$
}

\begin{abstract}
This paper reports a study conducted to investigate social studies and science teachers' awareness on climate change and how professional development workshop "Awareness and Adaptation to Climate Change” affects teachers' awareness level. For this purpose, a total of 101 teachers from 8 different cities and 4 geographical locations participated in the workshops and took part in the study. For data collection purposes, the Awareness to Climate Change Questionnaire (ACCQ) was used. Analysis revealed no statistical difference among participating teachers' awareness level based on pre-test scores. The results show that although the environmental education community has spent significant time and energy in developing and disseminating alternative instructional strategies for use in all classroom levels, the conception of the climate change as a unity of interrelated elements, as a system, remains negligible.
\end{abstract}

\section{Introduction}

According to the United Nations Framework Convention on Climate Change, definition of climate change and adaptation has been accepted as the following statement; "In addition to the natural climate variability observed in a comparable time period, directly or indirectly, a change of climate in consequence of human activities disrupting the composition of the global atmosphere". The climate change has become one of the most serious environmental problems faced in the 21 st century threatening public health and food security [20]. Nonetheless, very few people are aware of negative effects of climate change. In other words, some people are aware of it and express concerns about climate change, but very few of them actually are acting on these concerns and taking steps to change their lifestyles or consuming habits and decisions accordingly [35]. Besides, in addition to the climate change that has been on-going for many years with natural processes, intense changes that increase with human effect at local areas, increases the importance of adaptation to climate change.
Increase in the number of the scientific research and findings about human caused-climate change are another indicator for threat to human-beings and the environment [32]. In addition, there is an increasing international acceptance that climate change is a serious threat to humans' well-being and environmental integrity [33]. Humans are most certainly involved in sparking global climate change, and its effects on human-beings and natural systems will be formidable, far and wide, and affect the most of physically and financially vulnerable people around the world [28]. Scientific consensus has largely concluded that human activities are conducing to increasing temperatures, and causing changes in climate [15].

According to the fourth report of the Intergovernmental Panel on Climate Change report released in 2007, the climate system is heated beyond doubt; since the middle of 20th Century and the majority of observed increase in average surface temperature is likely due to a strong increase in human-induced greenhouse gasses and it is emphasized that this evidence is more powerful than the previous evaluation report [12]. Detailed studies are needed and should be conducted on climate change in order to provide governments with information necessary for policy development and action. The generation of projects and in this regard the creation of necessary budget for these projects is suggested. In addition to the fourth report, in the 5th report published in September 2013, it is emphasized that, changes seen in all natural processes are rapidly increasing [12]. The seriousness of global warming can be illustrated with the level of increase of temperature in the last 30 year period which has not been encountered within the period of 1400 years. It is now observed that, in the period of 1880-2012 global average temperatures increased approximately $0.85^{\circ} \mathrm{C}\left(0.65^{\circ} \mathrm{C}-1.06^{\circ} \mathrm{C}\right)$. Within this frame work, in relation to climate change and its processes, the most recent scientific, technical and socio-economic information has been reported and published by the contribution and evaluation of scientists in public and private sector. 
Most of the research on climate change focus on public understanding of climate change for the purpose of identifying human perception on the topic. Many scholars have analyzed the issue of climate change in recognition of public perception. [23]. Scientific and policy discussions of climate change could lie in roots of improved understanding of public perception. Scientists need to know how the public is likely to respond to climate impacts or initiatives since those responses can qualify or amplify the impacts [2]. Thus and so, a public awareness is crucial to firstly understand the negative effects of human actions and secondly to take action for prevention and adaptation to climate change. Consequently, climate change is a problem demanding a great deal of attention by scientists, policymakers, and the public as well; and for this reason, there has been recently a great interest in public understanding of climate change and in educating pupils, the future citizens, so as to enable them to successfully cope with this threat [19].

However, generally the term "climate change" is confused with the term "global warming" [26]. It is assumed that mass-media and teachers have a big role in this concept confusion. Many scholarly articles focus on mass media coverage of climate change studying the relation [27]. Moreover, there are studies on how the media affects public understanding of climate change. Even though there are studies about teachers and climate change issues, there are not as many media studies [25]. This is the situation especially in Turkey. Teachers are the second influential population especially when students are in question. Teachers' awareness of climate change might provide teachers with more knowledge about the subject. Manteaw describes awareness as an action to global issues and sustainable development and, therefore, connects it to education [17]. To achieve that, importance of education, awareness and training is highlighted in changing behavior in the study by Leal Filho et al. [14]. According to Pruneau et al., climate change is an issue which affects all parts of life and requires education to be considered as a whole without the boundaries of disciplines [21]. For that, studies emphasize the importance of teachers giving high priority on climate change to assure a proper understanding on the content among their students. However, those researches also state that teachers' own knowledge on the content is inadequate to teach it. Additionally, Fortner states that "students and some teachers seem unable to recognize environmental issues [8].

In this study, teachers are studied as a bridge between the education and students- citizens of future. There is a positive correlation between teachers' awareness of climate change as their students. The more teachers' awareness of climate change is, the more their students' is. In Turkey, science and social science education curricula includes content closely related with the climate change science issues. That is why teachers from these two content areas were chosen to take part in this study. Climate change awareness of those teachers from different cities of Turkey is surveyed in this research.

\section{Background}

In the last decade, students' and adults' perception of global warming and other global environmental problems have been focus to many research especially issues in terms of causality, possible consequences, and possible cures [19].

Some of these research focuses on common sense in public about climate change (e.g. [26]; [28];;[32]). Moreover, far studies surveyed the causes of climate change (e.g. [5]; [18]; [22]). The results of these studies have revealed that many people holds misconceptions about the climate change science and, especially, are confused about the nature, reasons and results of it. Whitmarsh identifies education as a social solution of developing and understanding of the relations between nature and modern societies and developing sustainable actions as responsible citizens [34].

There are several qualitative and quantitative surveys about mass media coverage of climate change issues. Some of them are about effects of mass media coverage on public understanding climate change (e.g. [1]; [10]; [16]). Those studies concluded that the mass-media affects public comprehension of climate change. However, a special interest should be paid to teachers and prospective teachers perceptions on the topic due to their role in public understanding. There is a relationship between student learning outcomes and how they are taught which has been studied by various studies. Based on the outcome of these studies it is indicated that there is a direct and positive relationship between teachers' effectiveness and students' learning outcomes [24], [31]. Therefore, there has been a special interest in teachers' professional development. This study also takes teachers' role in public understanding especially on students into account.

Papadimitriou studied 'student teachers' perceptions on aspects of climate change as well as on greenhouse effect and ozone layer depletion" and as the author states, teachers were found to be unaware of the proper actions for the climate change. [19]. With the similar findings, Fortner and Dove manifested that teachers do not have adequate knowledge to develop awareness and spread it to others [8], [7]. Similar outcome was also stated in a study conducted in Turkey by Celikler and Aksan, which showed that teachers' awareness on 
environmental issues was inadequate [3]. Each of the studies above indicates that teachers have problems with awareness of the Earth system relationships and the impact of human activities on earth systems. Many researchers argue on the importance of professional development opportunities for teachers especially on subject matter content knowledge since research addresses lack of content knowledge of teachers as an issue [9], [13].

The research reported here focuses on Turkish teachers' understanding of climate change with an aim to provide information that can be useful for the Turkish teachers in planning and organization. As part of the project, 'The Impacts of Climate Change and Raising Awareness about Adapting the Climate Change', this study intends to explore teachers' understanding about climate change. However, the impetus of this study is based on the need for valid and reliable instruments to measure knowledge of and attitudes toward climate change so that effective curriculum and instructional implementation can be measured.

The aim of the project 'The Impacts of Climate Change and Raising Awareness about Adapting the Climate Change' is to develop national and regional capacity to manage climate change risks at urban, rural and coastal areas of Turkey and to create awareness on impacts and adaptation to the climate change by providing teachers with more information about the issue. The project includes in-service teacher training on Climate Change Adaptation and Awareness through workshops. While the project aims to develop an awareness and understanding on climate change and to raise awareness in creating innovative ideas on how to be environmentally friendly at individual and social perspective, the purpose of this study is adaptation of an instrument that can be used to investigate individuals understanding and experiences about climate change and investigate teachers' perceptions on the matter.

\subsection{Professional Development Program; "Awareness and Adaptation to Climate Change"}

The professional development program titled "awareness and adaptation to climate change" was designed as a three-day in-service workshop focusing on global climate change. Teachers selected for the workshops were asked to be present on campus one day prior and introductory activities were conducted to familiarize teachers with the workshop programs as well faculty members and facilities.

Each day of the workshops was organized around a special theme. The emphasis of the first day of the program was given to ecology, environmental problems that we face mostly in the last century especially global warming, and sustainable development. The theme of the second day was climate change, its impacts and consequences for us and the ways to be followed for adaptation and mitigation. Finally, on the third day the focus was on energy that involves the subtopics of efficient ways of energy consumption and sustainable energy resources in the world. The workshops were structured around instruction, discussions, hands on activities and field trips. Morning sessions of each day was consists of instructions and discussions directed by academic scholars who are experts on the content. During these sessions teachers were able to share their ideas and brainstorm on the selected theme and discuss environmental issues.

The main aim of the afternoon sessions was provide teachers with first-hand experience with climate change activities, which they can later implement in their own classrooms. The activities were designed on four themes 1 - the effects of waste on climate change and the importance of waste reduction and management; 2 - biodiversity and its importance, 3 - Scavenger hunt activity about climate change, and 4-energy-saving. In addition to the teaching activities, field trips were also included in the workshop program such as the trip to a waste management center, named Izmit Waste and Residue Treatment, Incineration and Recycling Co Inc. Throughout the field trip teachers were given information by the experts of the center how the waste of the whole city is treated and recycled in the process. Benefit of being part of such an experience was to fold for the teachers; first of all they were able experience a waste management facility and learn about how different wastes need to be treated and disposed for the sake of environment and importance of waste management. And second by taking part in a field trip they were able to experience the educational value of field trips as a part of learning process.

Another activity that took place during the workshops was the science show on carbon cycle. This show integrates science into theatre and was a good opportunity to show teachers the value of informal learning environments for effective teaching and learning. Science show was very attractive for teachers, which also had the potential to encourage them for such cooperation with local groups where they can present their own students with learning environment that are fun and motivating. The workshop also included a session on developing projects. The purpose of this session was to provide teachers with tools necessary that they can develop their own projects with their students about environmental problems, especially climate change, and how they can prepare action plans. Each evening of the workshops were dedicated to either movie or documentary on global climate change and discussions where teachers got the opportunity to closely interact with other teachers as well as the instructors. 


\section{Purpose of the Research}

With the consideration of the importance of teachers' role on students' understanding and achievement this study focuses on teachers' perception of climate change. For this purpose selected teachers were invited to take part in a professional development opportunity focusing on climate change and its' impact on environment.

The study was conducted with the following research questions in mind; 1- How teachers perceive climate change? 2- Is there a difference between teachers' perceptions on the issue depending on the geographical locations they are selected from? 3How effective is the professional development program?

Overall this study and thus this project aim to provide teachers with effective professional development programs focusing on climate change and increase the awareness on issues and adaptation behavior.

\section{Methodology}

\subsection{Sample}

The strategy for the selection of participants was convenient sampling. As displayed in Table 1, the present study involved a total of 101 teachers from the four different regions, (Marmara, Aegean, Black Sea and Central Anatolia) and 8 different cities, (Edirne, Bursa, Konya, Kayseri, İzmir, Muğla, Trabzon, Samsun) of Turkey nearly in equal numbers. These geographical regions and cities were selected as pilots. Teachers who are teaching science education and social sciences education content areas for the study. The reason of choosing teachers from these two disciplines was the education programs of these two content areas. In middle school grade levels, climate change is taught in as a part of science and social sciences curriculum.

Among all the participants, more than half of the participants were male and majority of the teachers have medium or high experience based on their years in teaching. In addition, majority of the teachers hold an undergraduate degree.

In addition to demographics presented in Table 1, teachers were asked whether they attended any training before or worked in a project on climate change or global warming. Unfortunately, more than half of the teachers responded that they did not attend any training before neither worked in a project. Hence, for most of the teachers, this training was the first they attended in their professional career.
Table 1. Demographics

\begin{tabular}{lcc}
\hline & Frequency & Percent \\
\hline Gender & 39 & \\
\hline Female & 62 & 38,6 \\
Male & & \\
\hline City & 28 & 27,4 \\
\hline Edirne-Bursa & 24 & 23,8 \\
Konya-Kayseri & 26 & 25,7 \\
İzmir-Muğla & 23 & 22,8 \\
Trabzon-Samsun & & \\
\hline Teaching area & 54 & 53,5 \\
\hline Science education & 47 & 46,5 \\
Social sciences & & \\
\hline Experience & 12 & 11,9 \\
\hline $0-5$ & 48 & 47,5 \\
6-15 & 40 & 39,6 \\
16-35 & & \\
\hline Education level & 1 & 1,0 \\
\hline Two-year college & 92 & 91,1 \\
BS & 4 & 4,0 \\
MS & & \\
\hline Attended any training? & 34 & 33,7 \\
\hline Yes & 64 & 63,4 \\
No & & \\
\hline Worked in a project? & 69 & 68,3 \\
\hline Yes & & \\
No & & \\
\hline & & \\
\hline
\end{tabular}

\subsection{Data-Collection Instrument}

The instrument used for the purpose of data collection was titled "Awareness to Climate Change Questionnaire" (ACCQ), which was developed by Halady and Rao in 2010 [11]. The questionnaire includes Likert tipe items where, 1: I'm not aware, 2: I'm somewhat aware, 3: I'm aware, and 4: I'm strongly aware. Questionnaire measures the awareness level on different aspects of climate change and aims to determine any statistical significance between awareness and behavioral change. The final ACCQ was found to accurately measure whether awareness to the climate change phenomenon leads to significant behavioral change, alleviating the potential and existing threats of climate change phenomenon [11].

The ACCQ was comprised of four sections: Reasons and impacts of climate change; awareness of individual initiative; awareness of what industry can do; and propensity for behavioral change. Table 2 presents the sections of the questionnaire. The reported factors under each section were tested by confirmatory factor analysis for validation among adult participants in Turkish context in a prior adaptation study [6]. During the adaptation study, in order to ensure factorial validity of the scale model 
fit indices were examined deeply. In this sense, CMIN/df values were between 2 and 5, Comparative Fit Indexes (CFI) were close to 1 , the root mean square error of approximation (RMSEA) values were less than .05, standardized root mean square residuals (SRMR) were found less than .10 for all sections of the scale. CFA results showed that this questionnaire was found to be acceptable regarding to factorial validity [6]. The alpha coefficient of the instrument was calculated as .97 which also corresponds with the original study and indicated that instrument is valid.

Table 2: The factors for each of the four sections in the ACCQ reported by the original study and adapted in the Turkish context

\begin{tabular}{|c|c|}
\hline $\begin{array}{l}\text { Section of } \\
\text { Questionnaire }\end{array}$ & Factors reported \\
\hline \multirow{3}{*}{$\begin{array}{l}\text { Reasons and impacts } \\
\text { of climate change }\end{array}$} & Impact on health (9 items) \\
\hline & Water level (5 items) \\
\hline & $\begin{array}{l}\text { Reasons causing climate } \\
\text { change ( } 3 \text { items) }\end{array}$ \\
\hline \multirow[t]{5}{*}{$\begin{array}{l}\text { Awareness of } \\
\text { individual initiative }\end{array}$} & $\begin{array}{l}\text { Energy conservation (13 } \\
\text { items) }\end{array}$ \\
\hline & $\begin{array}{l}\text { Reduce GHG in car use ( } 5 \\
\text { items) }\end{array}$ \\
\hline & $\begin{array}{l}\text { Active environmentalist ( } 5 \\
\text { items) }\end{array}$ \\
\hline & Climate change \\
\hline & lighting (2 items) \\
\hline \multirow[t]{3}{*}{$\begin{array}{l}\text { Awareness of what } \\
\text { industry can do }\end{array}$} & $\begin{array}{l}\text { Conservation of energy ( } 8 \\
\text { items) }\end{array}$ \\
\hline & $\begin{array}{l}\text { Climate change friendly } \\
\text { material (6 items) }\end{array}$ \\
\hline & Systems (1 items) \\
\hline \multirow[t]{2}{*}{$\begin{array}{l}\text { Propensity for } \\
\text { behavioral change }\end{array}$} & $\begin{array}{l}\text { Behavioral change to } \\
\text { climate change }(6 \text { items })\end{array}$ \\
\hline & $\begin{array}{l}\text { Lead climate change } \\
\text { campaign }(2 \text { items })\end{array}$ \\
\hline
\end{tabular}

\subsection{Data-Collection Procedure and Analyses}

The pre- and post-test approach was adapted for the data collection purposes. The data collection was completed on site by the researchers. The participation to the study was voluntary and teachers had the right to withdraw from the study at any time if they chose to do so.

The study aimed to identify if there is any change of climate change awareness among teachers after attending the in-service training. For this purpose, initially an analysis of variance test used to examine whether there were any differences among participants originating from different geographical regions of Turkey based on pre-test scores. Further analysis was conducted through paired sample t-test analysis.

\section{Results}

The framework for the analysis was adapted from the original study conducted by Halady and Rao with the consideration of research questions. The analysis revealed the following results [11].

Science and social science teachers' climate change awareness:

\section{Anova}

Analysis of variance was conducted to examine whether there were any differences in groups' climate change awareness before the in-service training. For this purpose, pre-test scores were used which were collected during day 0 of the workshops. As displayed in Table 3, Anova results revealed that there were no statistical difference among four groups in terms of climate change awareness before the training $\mathrm{F}(3,97)=.525, \mathrm{p}=.66$. Therefore, for further analysis all of the participants were considered as the unit of analysis as a whole rather than taking the geographical or city origin in to account.

Table 3: Anova results

\begin{tabular}{llll}
\hline & df & F & Sig. \\
\hline Between groups & 3 & .525 & .666 \\
\hline
\end{tabular}

\section{T-test analyses}

Paired sample t-test analysis was conducted to investigate the impact of the "awareness and adaptation to climate change" workshops and whether there was a difference between teachers' pre and post-test awareness scores. The findings of the analyses are displayed in Table 4.

Table 4: Paired sample T-test statistics

\begin{tabular}{llllll}
\hline & & $\mathrm{t}$ & $\mathrm{df}$ & Sig. & $\begin{array}{l}\text { Eta- } \\
\text { squared }\end{array}$ \\
\hline Pair & ACC1- & - & 85 & $.000^{*}$ & .31 \\
ACC2 & & 6,297 & & & \\
\hline
\end{tabular}

As seen from the Table 4, there was a statistically significant difference between the mean scores of science and social science teachers' overall awareness to climate change before and after the inservice training. The eta-squared statistics .31 indicated a moderate effect size [4].

Having established that there was a statistically significant difference, the mean values were examined to find which set of scores were higher (ACC1 or ACC2). The pre-test mean scores of overall climate change awareness was calculated 3,31 meaning that teachers reported that they are 
aware of the topic. The post-test mean score was calculated as 3,84 indicating a stronger awareness presented in Table 5. Based on the calculated mean values and t-test analysis a statistically significant increase was found between pre- and post-test scores of the participating teachers.

Table 5: Comparison of teachers' climate change awareness

\begin{tabular}{rll}
\hline & $\mathrm{N}$ \\
\hline Pair ACC1 & 86 \\
ACC2 & 86 \\
\hline
\end{tabular}

In detail, Table 6, which is presented below, displays the significance values concerning the four sub-dimensions of the "Awareness to Climate Change Questionnaire": 1- reasons and impacts of climate change, 2 - awareness of individual initiative, 3 - awareness of what industry can do, 4 - tendency for behavioral change.

Table 6: T-test results considering each subdimension

\begin{tabular}{|c|c|c|c|}
\hline Sub-dimension & $\begin{array}{c}\text { Pretest } \\
\text { mean }\end{array}$ & $\begin{array}{l}\text { Posttest } \\
\text { mean }\end{array}$ & Probability \\
\hline $\begin{array}{l}\text { Reasons and } \\
\text { impacts of climate } \\
\text { change }\end{array}$ & 3.18 & 3.67 & $.000 *$ \\
\hline $\begin{array}{l}\text { Awareness of } \\
\text { individual initiative }\end{array}$ & 3.40 & 3.83 & $.000 *$ \\
\hline $\begin{array}{l}\text { Awareness of what } \\
\text { industry can do }\end{array}$ & 3.24 & 3.80 & $.000 *$ \\
\hline $\begin{array}{l}\text { Tendency for } \\
\text { behavioral change }\end{array}$ & 3.30 & 3.73 & $.000 *$ \\
\hline
\end{tabular}

As seen from the results, it can be determined from the pre-test scores that teachers share a reasonably acceptable level of awareness for subscales of reasons and impacts of climate change, awareness of individual initiative, awareness of what industry can do, and tendency for behavioral change. However, an increase in awareness was identified when post-test scores were analyzed in comparison to pre-test scores indicating a stronger awareness on all sub-dimensions, which can be attributed to the inservice workshops.

\section{Discussion}

Teachers' understanding and awareness on environmental issues such as climate change are vital for development of an understanding in larger scale especially when younger generations are in question. Therefore educational opportunities focusing on teachers' knowledge, understanding and awareness have value and their impact should be studied for development of better learning opportunities. To this end, this study was focusing on teachers' awareness on climate change and was investigating the impact of professional development workshop, "Awareness and Adaptation to Climate Change".

Social studies and science teachers from four different locations took part in the study and based on the pre-test scores no statistical difference were found among participating teachers' awareness on climate change. This outcome may be attributed to the fact teachers may be representing various Mdifferent cities or geogra ilical locations regardless 3.the city there are working 40 . Pre-test results also 3. Eexealed that although climptoe change is related to their field of teaching, social studies and science inservice teachers are unaware of the climate change issue. For each sub-dimension of reasons and impacts of climate change, awareness of individual initiative, awareness of what industry can do, and tendency for behavioral change, the mean values were ranged between 3.18 and 3.40. That shows, teachers have quite a low level of awareness regarding climate change. Although there is very limited number of studies on in-service teachers' climate change awareness, existing research studies have also revealed similar results. For instance, Papadimitriou asserted that prospective teachers, enter the university holding many misconceptions and misunderstandings concerning climate change [19]. After starting the field as a teacher, these misconceptions may tend to become persistent and very resistant to change. Similarly, in a study focusing on Vietnamese primary teachers' awareness on environmental problems and as teachers their capacities to meet the requirements of environmental education, then revealed that both the awareness and capacities of Vietnamese primary school teachers on environmental education were insufficient [30].

Second part of the analysis investigated the impact of the workshop on teachers' awareness. For both overall questionnaire and subscales analysis revealed that teachers have awareness on the topic. Since both social studies and science curriculum include content on climate change it is expected to have teachers to have at least a basic understanding and awareness on the topic. However, since this study does not focus on teachers' knowledge on the content it is not possible to predict on the knowledge level of the participants on climate change. When post-test scores were analyzed an increased level of awareness were found. Although the increase in teachers' awareness of global climate change is not large, this outcome shows a positive impact of the workshop on participating teachers' awareness on climate change.

\section{Implications and Conclusion}

Since when the climate change was being accepted as one of the most important issues of the new century, individuals' behaviour, perceptions, 
knowledge and awareness in relation to climate change mitigation and adaptation were started to be the focus of research studies [34]. In order to rise the new generations with an awareness and perception of climate change issue has been one of the aims of science education. To this end, first of all, teachers' behaviors, perceptions, and awareness are vital to be increased. Besides, majority of teachers are unfamiliar to educate students about issues such as climate change since they heavily based their teaching on traditional didactic strategies [19]. Therefore, like in the present study, the number of in-service teacher training workshops aiming to increase both teachers' awareness on climate change and to develop their teaching strategies and skills regarding climate change should be increased.

Apart from the efforts for in-service teachers, in order to raise teachers with an awareness of environmental problems such as climate change and capabilities to teach these topics, it may be better to integrate climate change education into teacher education programs for both social science and science education teachers. For instance, it may be helpful to design courses about climate change awareness. Besides, pedagogical courses focusing specifically on the instructional skills for the teaching of environmental problems such as climate change may provide teachers with the competencies to teach climate change in science classrooms.

Workshops such as "Awareness and Adaptation to Climate Change", which integrates instruction and teaching activities, creates opportunities for teachers who are already in workforce to keep up with the changing nature of knowledge and follow recent scientific developments. Although the study was not focusing on teachers' content knowledge, as seen from this study the professional development workshop has a positive influence on teachers' awareness. For further studies, it is recommended to focus on the content knowledge as well.

\section{References}

[1] Antilla, L., "Self-censorship and science: a geographical review of media coverage of climate tipping points", Public Understanding of Science, 19(2), 2008, pp.240-256.

[2] Bord, R.J., Fisher, A., \& O'Connor, R.E., "Public perceptions of global warming: United States and international perspectives", Climate Research, 11, 1998, pp.75-84.

[3] Celikler, D., \& Aksan, Z., "Determination of preservice elementary science teachers' knowledge level about ozone layer", 3rd World Conference on Educational Sciences, 15, 2011, pp.1438-1444.

[4] Cohen, J. W., "Statistical power analysis for the behavioral sciences (2nd edn)", Hillsdale, NJ: Lawrance Earlbaum Associates, 1998.

[5] Crowley, T. J., "Causes of climate change over the past 1000 years”, Science, 14(289), 2000, pp.270-277.
[6] Dal, B., Ozturk, N., Alper U., Ozdem Y., \& Sonmez D., "A model for pre-service teachers' climate change awareness and behavior change: Adaptation of awareness to climate change questionnaire", International Research in Geographical and Environmental Education, 2015 (in press).

[7] Dove, J., "Student teacher understanding of the greenhouse effect, ozone layer depletion and acid rain", Environmental Education Research, 2(1), 1996, pp.89-100. [8] Fortner, R. W., "Climate change in school: Where does it fit and how ready are we?", Canadian Journal of Environmental Education, 6, 2001, pp.18-31.

[9] Garet, M. S., Porter, A. C., \& Desimone, L., "What makes professional development effective? Results from a national sample of teachers", American Educational Research Journal, 38(4), 2001, pp.915-45.

[10] Gavin, N. T. (2009). "Addressing climate change: a media perspective", Environmental Politics, 18(5), 765780.

[11] Halady, I. R., \& Rao, P. H., "Does awareness to climate change lead to behavioral change?", International Journal of Climate Change Strategies and Management, 2(1), 2010, pp. 6-22.

[12] Intergovernmental Panel on Climate Change (IPCC), "Climate Change 1995: The Science of Climate Change", Cambridge University Press, Cambridge. 1996.

[13] Kennedy, M. M., "Form and substance in in-service teacher education (Research Monograph No. 13)", Arlington, VA: National Science Foundation, 1998.

[14] Leal Filho, W., Pace, P., \& Manolas, E., "Education for Sustainable Development: Current discourses and practices and their relevance to Technology Education", In International Journal of Technology and Design Education, 19(1), 2008, pp.17-34.

[15] Louis, M. E., \& Hess, J. J., "Climate Change: Impacts on and Implications for Global Health", American Journal of Preventive Medicine, 35(5), 2008, pp.527-538.

[16] Lyytimäki, J., \& Tapio, P., "Climate change as reported in the press of Finland: From screaming headlines to penetrating background noise", International Journal of Environmental Studies, 66(6), 2009, pp.723-735.

[17] Manteaw, O. O., "Education for sustainable development in Africa: The search for pedagogical logic", International Journal of Education Development, 32, 2012, pp.376-383.

[18] Öztürk, K., "Küresel iklim değişikliği ve Türkiye’ye olas1 etkileri”, Gazi Eğitim Fakültesi Dergisi, 22, 2002, pp.47-65.

[19] Papadimitriou, V., "Prospective primary teachers' understanding of climate change, greenhouse effect, and ozone layer depletion", Journal of Science Education and Technology, 13(2), 2004, pp.299-307.

[20] Parry, M., Rosenzweig, C., Iglesias, A., \& Fischer, G., "Climate change and world food security: a new assessment”, Global Environmental Change, 9, 1999, pp. 51-67.

[21] Pruneau, D., Liboiron, L., Vrain, E., Gravel, H., Bourque, W., \& Langis, J., "People's ideas about climate change : A source of inspiration for the creation of educational programs", Canadian Journal of Environmental Education, 6, 2001, pp.121-138.

[22] Sağlam, N. E., Düzgüneş, E. \& Balık, I., "Global warming and climatic changes", E. U. Journal of Fisheries \& Aquatic Sciences, 25(1), 2008, pp.89-94.

[23] Sampei, Y., \& Aoyagi-Usui, M., "Mass-media coverage, its influence on public awareness of climate- 
change issues, and implications for Japan's national campaign to reduce greenhouse gas emissions", Global Environmental Change, 19, 2009, pp.203-212.

[24] Sanders, W. L., \& Rivers, J. C., "Cumulative and residual effects of teachers on future student academic achievement", University of Tennessee, Value-Added Research and Assessment Center, 1996.

[25] Savaşçı-Açıkalın, F., \& Açıkalın, M., "Pre-service teachers' conceptions of environmental issues", Conference on urban education, September 13-16, 2011, Berlin, Germany.

[26] Schuldt, J. P., Konrath, S. H., \& Schwarz, N., "Global warming" or "climate change'? whether the planet is warming depends on question wording", Public Opinion Quarterly, 75(1), 2011, pp.115-124.

[27] Segev, E., \& Baram-Tsabari, A., "Seeking science information online: Data mining Google to beter understand the roles of the media and the education system", Public Understanding of Science, 21(7), 2010, pp.813-829.

[28] Semenza, J. C., Hall, D. E., Wilson, D. J., Bontempo, B. D., Sailor, D. J., \& George, L. A., "Public Perception of Climate Change: Voluntary Mitigation and Barriers to Behavior Change", American Journal of Preventive Medicine, 35(5), 2008, pp.479-487.

[29] Sharma, A., "Global Climate Change: What has Science Education Got to Do with it?. Science \& Education, 21(1), 2012, pp.33-53.

[30] Than, N.T., "Awareness of Vietnamese primary schoolteachers on environmental education", International Research in Geographical and Environmental Education, 10(4), 2001, pp.429-444.

[31] Westerlund, J. F., "Summer scientific research for teachers: the experience and its effect", Journal of Science Teacher Education, 13(1), 2002, pp.63-83.

[32] Whitmarsh, L., "Behavioural responses to climate change: Asymmetry of intentions and impacts", Journal of Environmental Psychology, 29, 2009a, pp.13-23.

[33] Whitmarsh, L., "What's in a name? Commonalities and differences in public understanding of climate change and global warming", Public Understanding of Science, 18(4), 2009b, pp.401-420.

[34] Whitmarsh, L., "Perceptions, behavior, and communication of climate change", WIREs Climate Change, 1, 2010, doi: 10.1002/wcc.7.

[35] Whitmarsh, L., \& Köhler, J., "Climate change and cars in the EU: the roles of auto firms, consumers, and policy in responding to global environmental change", Cambridge Journal of Regions, Economy and Society, 3, 2010, pp. 427-441. 